\title{
AKTIVITAS ESTROGENIK EKSTRAK ETANOL 70\% HERBA KEMANGI (Ocimum americanum L.) PADA TIKUS PUTIH BETINA (Rattus norvegicus) PRE- MENOPAUSE
}

\author{
E.Mulyati Effendi ${ }^{1}$, Hera Maheshwari ${ }^{2}$, Mega Listya M.I ${ }^{3}$ \\ ${ }^{1,3)}$ Program Studi Farmasi FMIPA Universitas Pakuan \\ ${ }^{2)}$ Fakultas Kedokteran Hewan Institut Pertanian Bogor \\ Email : mulyatichandra@ymail.com
}

\begin{abstract}
ABSTRAK
Ocimum americanum L.(Lamiaceae) dikenal sebagai Kemangi di Indonesia, merupakan tanaman semak dengan bau aromatik yang kuat. Bagian daun dan akar secara tradisional digunakan untuk berbagai pengobatan. Tujuan penelitian ini adalah untuk mengetahui aktivitas estrogenik ekstrak etanol 70\% herba kemangi (Ocimum americanum L.) pada tikus putih betina (Rattus norvegicus) pre-menopause. Sebanyak 20 tikus putih betina dibagi menjadi 5 kelompok perlakuan, masing-masing diberi perlakuan dengan etinil estradiol (kontrol positif), CMC-Na 1\% (kontrol negatif), ekstrak etanol 70\% dosis I, II dan II $(0,8 \mathrm{~g} / 200 \mathrm{gBB}, 1,6 \mathrm{~g} / 200 \mathrm{gBB}, 3,2 \mathrm{~g} / 200 \mathrm{gBB})$. Siklus estrus, vaskularisasi ovarium dan uterus diamati untuk mengetahui efek dari masing-masing perlakuan. Perlakuan dosis $0,8 \mathrm{~g} / 200 \mathrm{~g} \mathrm{BB}$ dapat memperpanjang siklus estrus, meningkatkan vaskularisasi dan bobot ovarium dibandingkan dengan kontrol negatif dan setara dengan etinil estradiol $\left(9 \times 10^{-3} \mathrm{mg} / 200 \mathrm{gBB}\right)$.
\end{abstract}

Kata kunci: Herba kemangi, estrogenik, pre-menopause

\section{ESTROGENIC ACTIVITIES OF ETHANOLIC 70\% EXTRACTED OF KEMANGI (Ocimum americanum L.) HERBS IN PRE-MENOPAUSE FEMALE WHITE RATS (Rattus norvegicus)}

\begin{abstract}
Ocimum americanum L.(Lamiaceae) commonly known as Kemangi in Indonesia, is a small shrub with strong aromatic odor. The plant leaves and roots are traditionally used to possess a wide range of medicinal activities. The main objective of this study is to evaluate the estrogenic activity of $70 \%$ ethanol basil herbs extract in female white rats (rattus norvegicus) pre-menopause use whitten effect method. Twenty female white rats were divided into five treatment groups, each group treated with ethynil estradiol (positive control), CMC-Na $1 \%$ (control negative), $70 \%$ ethanol extract dose I, II and II $(0.8 \mathrm{~g} / 200 \mathrm{~g}$ $\mathrm{BW}, 1.6 \mathrm{~g} / 200 \mathrm{~g} \mathrm{BW}, 3.2 \mathrm{~g} / 200 \mathrm{~g} \mathrm{BW})$. Estrus cycle, uterine and ovarian vascularization evaluated to know the effect of each treatment. Dose treatment of $0.8 \mathrm{~g} / 200 \mathrm{~g} \mathrm{BW}$ has resulted in extended estrus cycle, improved vascularization and ovarian weights compared with negative control and equal with etinil estradiol $\left(9 \times 10^{-3} \mathrm{mg} / 200 \mathrm{~g} \mathrm{BW}\right)$.
\end{abstract}

Key words: Ocimum americanim L. herbs, estrogenic, pre-menopause

\section{PENDAHULUAN}

Indonesia merupakan negara yang beriklim tropis dan kaya akan sumber daya alam dengan berbagai macam tanaman obat yang yang dapat digunakan sebagai obat tradisional. Berbagai macam tanaman obat 
telah terbukti mengobati berbagai macam penyakit, tetapi secara ilmiah masih belum dapat dipertanggung jawabkan.

Salah satu tanaman obat yaitu kemangi (Ocimum americanum L.) famili Lamiaceae (Labiatae) memiliki bau dan rasa yang khas, digunakan sebagai lalapan segar untuk dimakan dan memiliki berbagai macam khasiat (Hadipoentyanti \& Wahyuni, 2008). Spesies Ocimum merupakan salah satu tanaman yang berkhasiat sebagai kemopreventif dan berkhasiat sebagai obat (Karthikeyan et al., 1999, Rastogi et al., 2007). Kandungan utamanya adalah minyak atsiri, flavonoid, fitosterol, karbohidrat dan tanin. Penggunaannya yang utama sebagai antimikroba, antioksidan, antelmintika dan antidiabetika (Khare, 2007). Adanya anetol, boron dan stigmasterol merupakan senyawa aktif pada kemangi yang berhubungan dengan aktivitas seksual yaitu merangsang keluarnya hormon reproduksi yaitu estrogen (Gunawan, 2004).

Whitten Effect merupakan metode yang digunakan untuk mengamati perubahan yang terjadi pada vagina untuk menentukan siklus estrus (persiapan kawin) pada hewan laboratorium kecil seperti mencit atau tikus putih (Ochiogu et al., 2009; Khazaei et al., 2011). Durasi siklus estrus pada mencit selama 4-6 hari, tahap siklus estrus dapat dilihat pada perubahan sel epitel vagina atau vulva. Ciri-ciri hewan estrus dapat dilihat dari keadaan vulva yang bengkak, berwarna merah dan basah (Nongae, 2008). Sinkronisasi birahi pada tikus betina dengan mencium bau feromon yang keluar bersama urin tikus jantan. Ketika tikus betina tidak membau feromon tikus jantan, maka tikus betina mengalami fase anestrus, sedangkan pada saat tikus betina membau feromon yang ikut disekresikan bersama urin tikus jantan, maka pada hari ke 3 berikutnya tikus betina mengalami estrus. Pada fase estrus sel epitel berubah menjadi sel superfisial dan sel tanduk yang menandakan hewan dalam keadaan puncak estrus (Seire et al., 1991).

Berdasarkan penelitian sebelumnya diatas, maka tujuan penelitian ini adalah untuk mengetahui aktivitas estrogenik ekstrak etanol $70 \%$ herba kemangi pada tikus putih betina (Rattus norvegicus) premenopause juga melakukan pengamatan vaskularisasi ovarium dan uterus pada fase estrus.

\section{METODE PENELITIAN}

Penelitian ini dilaksanakan pada bulan Juni sampai September 2013 bertempat di Laboratorium Farmasi Universitas Pakuan.

\section{Bahan}

Tikus putih (Rattus norvegicus) betina galur Sprague-Dawley pre-menopause berumur 8-9 bulan dengan bobot badan sekitar 200-250 g sebanyak 20 ekor, $\mathrm{NaCl}$ fisiologis, herba kemangi, pewarna Giemsa, metanol $10 \%$, etanol $70 \%$, etinil estradiol dan CMC-Na $1 \%$.

\section{Alat}

Rotary evaporator (BUCHI), grinder, ayakan 40 Mesh, mikroskop, sonde, kaca arloji, stop watch, pengaduk gelas, alat maserasi, gelas kimia, kain flannel, timbangan analitik, perlengkapan untuk membuat preparat apus vagina (cotton bud, gelas objek, cawan petri, bunsen), kandang tikus ukuran 30 x $40 \mathrm{~cm}$, lampu, bak plastik, kawat penutup, dan botol minum.

\section{Cara Kerja}

Penelitian terbagi menjadi 2 tahap yaitu tahap pra-penelitian dan tahap penelitian.

\section{Ekstraksi}

Sebanyak $1 \mathrm{~kg}$ simplisia herba kemangi yang telah dihaluskan, dimaserasi dengan pelarut etanol $70 \%$ (perbandingan 1:10) dalam tabung selama 3 x 24 jam. Kemudian disaring dan ampasnya dimaserasi kembali sebanyak 2 kali dengan perlakuan yang sama. Maserat yang terkumpul dievaporasi dengan menggunakan rotary evaporator pada suhu $30-40^{\circ} \mathrm{C}$ hingga terbentuk ekstrak kental etanol. (Harborne, 1987).

\section{Penapisan Fitokimia}


Ekstrak kental di uji terhadap alkaloid, saponin, tanin, flavonoid dan steroid (Harborne, 1987).

\section{Tahap Pra-Penelitian}

a. Adaptasi dilakukan pada 20 ekor tikus betina (Rattus norvegicus) tikus percobaan selama 1 minggu dengan berat badan sekitar 200-250 g.

b. Setelah satu minggu, tikus-tikus percobaan tersebut dibagi menjadi 5 kelompok perlakuan dengan masingmasing kelompok terdiri dari 4 ekor tikus. Kelompok kontrol positif (P1) diberi per oral etinil estradiol dengan dosis $9 \times 10^{-3} \mathrm{mg} / 200 \mathrm{~g}$ BB dalam CMC$\mathrm{Na} 1 \%$ sebanyak $3 \mathrm{~mL}$ (Ganiswara, 1995).

c. Kelompok kontrol negatif (P2) diberi per oral CMC-Na 1\% / 200g BB sebanyak 3 mL. Kelompok Uji I (P3) diberi per oral ekstrak etanol $70 \%$ herba kemangi dengan dosis yang setara dengan $1 \mathrm{~mL}$ ekstrak kental dalam dosis $0,8 \mathrm{~g} / 200 \mathrm{~g}$ BB dalam CMC-Na $1 \%$ sebanyak $3 \mathrm{~mL}$. Kelompok Uji II (P4) diberi per oral ekstrak etanol $70 \%$ herba kemangi dengan dosis yang setara dengan $2 \mathrm{~mL}$ ekstrak kental dalam dosis 1,6g/200g BB dalam CMC-Na $1 \%$ sebanyak $3 \mathrm{~mL}$. Kelompok Uji III (P5) diberi per oral ekstrak etanol $70 \%$ herba kemangi dengan dosis yang setara dengan $4 \mathrm{~mL}$ ekstrak kental dalam dosis 3,2g/200g BB dalam CMC-Na $1 \%$ sebanyak $3 \mathrm{~mL}$. Semua perlakuan dilakukan secara per oral selama satu kali siklus estrus, dimulai pada saat berlangsungnya fase estrus. Penyeragaman saat fase estrus dilakukan dengan metode Whitten Effect dengan cara meletakkan kandang tikus jantan diatas kandang tikus betina.

\section{Tahap Penelitian}

Tahap penelitian dilakukan terhadap lama siklus estrus, vaskularisasi ovarium dan uterus dan bobot ovarium dan uterus pada fase estrus.

\section{a. Lama Siklus Estrus}

Pengamatan siklus estrus dilakukan setiap 3 jam setelah terjadinya estrus hingga estrus berikutnya dengan mengamati sel-sel yang ditemukan dalam apusan vagina secara mikroskopik. Pengamatan dilakukan selama 12 jam berdasarkan hasil penelitian bahwa pemberian daun kemangi dapat memperpanjang siklus estrus (Suntoro, 1983). Peengamatan fasse di dalam siklus estrus yaitu proestrus, estrus, metestrus dan diestrus dilakukan dengan pemeriksaan preparat ulas vagina kemudian diamati dengan mikroskop pembesaran 10x. Preparat apus vagina disiapkan dengan mengulaskan kapas (cutton bud) yang telah dibasahi dengan saline guna menghindari terjadinya iritasi ke dalam lubang vagina tikus kemudian diulaskan pada gelas objek (Suntoro, 1983). Sampel yang diperoleh kemudian difiksasi menggunakan metanol $10 \%$ selama 5 menit. Setelah itu preparat ulas diwarnai dengan pewarna Giemsa selama 30 menit, kemudian dicuci dengan akuades dan dikeringkan. Warna yang dihasilkan merah dadu (Beimborn et al., 2003).

\section{b. Vaskularisasi Ovarium Dan Uterus Pada Fase Estrus}

Pengamatan vaskularisasi ovarium dan uterus pada tikus betina dilakukan dengan cara mematikan tikus dengan eter pada saat tikus mengalami masa estrus, lalu dibedah untuk dikeluarkan ovarium dan uterusnya, setelah itu dilihat warna mukosa pada ovarium dan uterus tikus. Penilaian dan pengamatan vaskularisasi dinyatakan dengan skoring, sesuai dengan modifikasi metode (Setiawan, 2010).

\section{c. Pengukuran Bobot Ovarium dan Uterus Pada Fase Estrus}

Koleksi ovarium dan uterus dilakukan terlebih dahulu setelah pengamatan vaskularisasi, setelah itu dilakukan penimbangan bobot ovarium dan uterus. kemudian dilakukan penimbangan bobot ovarium dan uterus (Nodine \& Siegler, 1961).

\section{d. Rancangan Penelitian}

Pengaruh estrogenik dari ekstrak etanol $70 \%$ herba kemangi pada tikus putih betina dapat dilihat dari hasil penggunaan uji statistik Rancangan Acak Lengkap (RAL) 
dengan lima perlakuan dan enam ulangan. Apabila uji $\mathrm{F}$ menunjukkan pengaruh yang nyata dimana nilai $\mathrm{Fh}>0,05$, maka untuk melihat adanya perbedaan antar perlakuan, dilakukan uji lanjut menggunakan Uji Duncan. Sidik ragam untuk Rancangan Acak Lengkap disajikan pada Tabel (Sudjana, 1998).

\section{HASIL DAN PEMBAHASAN}

\section{Ekstraksi Dan Penapisan Fitokimia}

Ekstrak kental yang diperoleh $121 \mathrm{~g}$, maka rendemen ekstrak etanol $70 \%$ adalah $12,1 \%$. Berdasarkan hasil uji fitokimia kandungan ekstrak etanol $70 \%$ herba kemangi adalah saponin, tanin dan steroid. Senyawa saponin dan tanin memberikan efek antelmintika (Medica dkk., 2004). Kandungan utama Ocimum americanum L. selain minyak atsiri adalah flavonoid, karbohidrat, fitosterol dan tanin (Sarma \& A. Venkata, 2011). Fitosterol merupakan prekursor senyawa bioaktif steroid, faktor pertumbuhan dan substrat untuk sintesis senyawa metabolit sekunder pada tanaman (Piironen et al., 2003). Steroid merupakan struktur dasar hormon estrogen terutama sebagai hormon seks wanita. Estrogen dalam plasma hewan betina yang utama adalah 17 $\beta$-estradiol, estron, dan estriol (Johnson, \& Everitt, 1984).

\section{Pengaruh Pemberian Ekstrak Etanol 70\% Herba Kemangi Terhadap Lama Siklus Estrus}

Estrus merupakan fase periode birahi. Lama estrus pada tikus 9-20 jam dan siklus estrus berlangsung selama empat sampai enam hari. Siklus estrus dibagi menjadi empat fase yaitu fase proestrus, estrus, metestrus, dan diestrus (Turner \& Bagnara, 1976).

Hasil pengujian ekstrak terhadap lama siklus estrus dilakukan dengan mengamati sel-sel yang ditemukan dalam apusan vagina secara mikroskopik yang dapat dilihat pada Gambar 1.

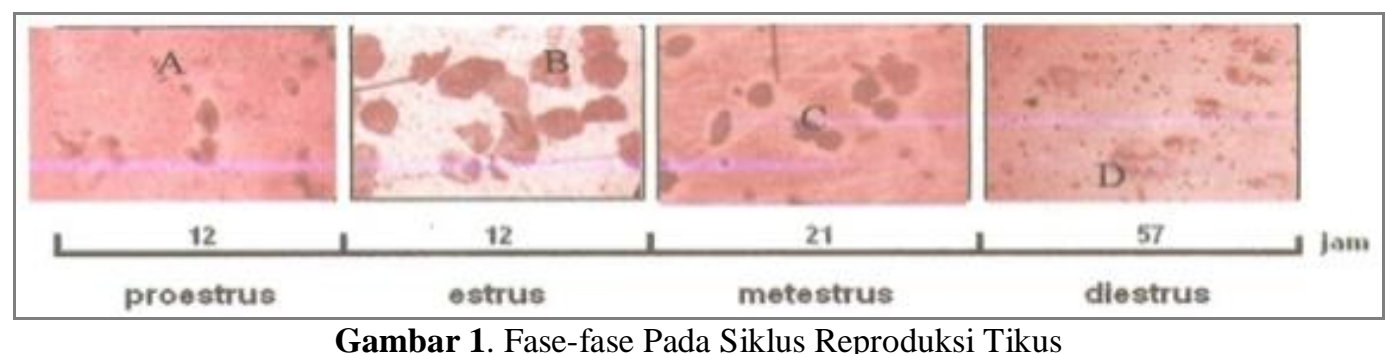

Gambar 1. Fase-fase Pada Siklus Reproduksi Tikus

Keterangan: A. Sel Epitel Berinti, B. Sel

Kornifikasi, C. Sel Tidak Berinti, D. Leukosit

Pada fase proestrus ditandai dengan sel epitel berinti banyak. Fase ini menandakan akan datangnya birahi (Turner \& Bagnara, 1976). Preparat apus vagina fase estrus ditandai dengan terbentuknya cornified cell (sel menanduk) sebagai gambaran banyaknya mitosis yang terjadi di dalam mukosa vagina. Menjelang estrus berakhir, lumen vagina membentuk sel-sel menanduk dengan inti berdegenerasi (Turner \& Bagnara, 1976). Pada fase metestrus sel menanduk berkurang dan ovary mengandung korpus luteum yang mengandung sel-sel lutein dan folikel-folikel kecil yang tidak berinti. Fase diestrus didominasi oleh sel leukosit dan mulai muncul sel epitel berinti (Turner \& Bagnara, 1976).

Waktu siklus estrus ditampilkan pada Tabel 1 yang menunjukkan bahwa perlakuan ekstrak etanol $70 \%$ herba kemangi dengan konsentrasi terendah mengalami estrus selama 165 jam (mendekati 7 hari) sudah setara dengan kontrol positif dan konsentrasi tertinggi. Durasi total siklus estrus (proestrus, estrus, metaestrus dan diestrus) adalah 4-5 hari (Waynforth, \& Flecknell, 1992). Perlakuan kontrol negatif (CMC-Na1\%) memberikan waktu siklus estrus yang paling pendek yaitu 107 jam dibandingkan ke empat kelompok perlakuan 
lainnya. Hasil uji statistik menunjukkan bahwa CMC-Na 1\%, etinil estradiol, ekstrak etanol $70 \%$ herba kemangi dosis $0,8 \mathrm{~g} / 200 \mathrm{~g}$ $\mathrm{BB} ; 1,6 \mathrm{~g} / 200 \mathrm{~g}$ BB dan 3,2g/200g BB memberikan pengaruh yang sangat beda nyata terhadap peningkatan (lebih lamanya) waktu siklus estrus $(\mathrm{P}<0,01)$.

Hasil uji Duncan untuk mengetahui perbedaan antar perlakuan menunjukkan bahwa, semua perlakuan pemberian ekstrak etanol $70 \%$ herba kemangi pengaruhnya sama dengan etinil estradiol $9 \times 10^{-3}$ $\mathrm{mg} / 200 \mathrm{gBB}$ sebagai kontrol positif terhadap memperpanjang siklus estrus pada tikus putih betina pre-menopause. Melalui pemberian dosis terendah yaitu $0,8 \mathrm{~g} / 200 \mathrm{~g}$ BB pengaruhnya sudah setara dengan kontrol positif dengan perbedaan yang sangat nyata terhadap memperpanjang siklus estrus.

Data pengukuran waktu siklus estrus dapat dilihat pada Tabel 1.

Tabel 1. Waktu Siklus Estrus.

\begin{tabular}{cccccc}
\hline Jumlah & \multicolumn{5}{c}{ Lamanya Siklus (jam) Perlakuan } \\
\cline { 2 - 5 } Ulangan & $\mathrm{P} 1$ & $\mathrm{P} 2$ & $\mathrm{P} 3$ & $\mathrm{P} 4$ & $\mathrm{P} 5$ \\
\hline 1 & 165 & 100 & 165 & 159 & 174 \\
2 & 163 & 120 & 165 & 165 & 165 \\
3 & 165 & 104 & 165 & 174 & 165 \\
4 & 164 & 104 & 165 & 165 & 165 \\
Total & 657 & 428 & 660 & 663 & 669 \\
Rata-rata & $164.3^{\mathrm{a}}$ & $107^{\mathrm{a}}$ & $165^{\mathrm{ac}}$ & $165.75^{\mathrm{ac}}$ & $167.3^{\mathrm{ac}}$ \\
\hline
\end{tabular}

Keterangan : Angka yang diikuti superkrip yang sama pada baris yang sama menunjukkan pengaruh yang tidak berbeda nyata $(\mathrm{P}>0.05)$.

Hasil pada pengujian ini menunjukkan bahwa dengan pemberian ekstrak herba kemangi meyebabkan terjadinya peningkatan hormon estrogen pada fase estrus sehingga cenderung akan memperpanjang siklus estrus.

\section{Vaskularisasi Ovarium Dan Uterus Pada Fase Estrus}

Pengujian ekstrak etanol $70 \%$ herba kemangi terhadap vaskularisasi uterus dan ovarium menggunakan modifikasi metode Rugh (1968) berdasarkan skoring yang dapat dilihat dari perbedaan mukosa ovarium dan uterus pada Gambar 2 di bawah ini.

Estrogen bertanggung jawab terhadap peningkatan jumlah buluh darah ke uterus. Peningkatan jumlah vaskularisasi pada uterus akan memperlancar aliran darah ke uterus (Albrecht \& Pepe, 2007).

Hasil pengujian menunjukkan bahwa ekstrak etanol herba kemangi pada dosis $0,8 \mathrm{~g} / 200 \mathrm{~g}$ BB mampu meningkatkan vaskularisasi dari mukosa ovarium dan uterus tikus dibandingkan dengan kontrol negatif. Hal ini terlihat dari penilaian yang dilakukan secara deskriptif. Berdasarkan hasil skoring, dosis $3,2 \mathrm{~g} / 200 \mathrm{~g}$ BB bernilai rata-rata 3 untuk setiap ulangan (Tabel 2). Pada dosis 1,6g/200g BB menunjukkan terjadinya peningkatan vaskularisasi mukosa yang sama dengan dosis $0,8 \mathrm{~g} / 200 \mathrm{~g}$ BB dimana nilai rata-rata skoring adalah 2,7. Kontrol negatif memberikan skoring vaskularisasi mukosa ovarium dan uterus yang paling rendah.

Pemberian ekstrak etanol herba kemangi pada dosis 3,2g/200gBB dapat menghasilkan warna yang sangat merah pada mukosa uterus dan ovarium tikus. Hal ini disebabkan ekstrak etanol herba kemangi bersifat estrogenik yang dapat meningkatkan vaskularisasi. Hasil uji statistik, diketahui bahwa CMC-Na1\%, etinil estradiol $9 \times 10^{-3}$ $\mathrm{mg} / 200 \mathrm{~g} \mathrm{BB}$, ekstrak etanol herba kemangi $0,8 \mathrm{~g} / 200 \mathrm{~g}$ BB sebagai dosis uji I, ekstrak etanol herba kemangi $1,6 \mathrm{~g} / 200 \mathrm{~g}$ BB sebagai dosis uji II dan ekstrak etanol herba kemangi 3,2g/200g BB sebagai dosis uji III memberikan pengaruh yang beda nyata terhadap vaskularisasi pada ovarium dan 
uterus $(\mathrm{P}<0,05)$. Penentuan perbedaan antar perlakuan dilanjutkan dengan uji Duncan.

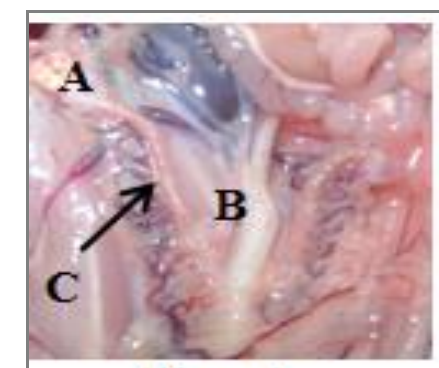

Skor 0

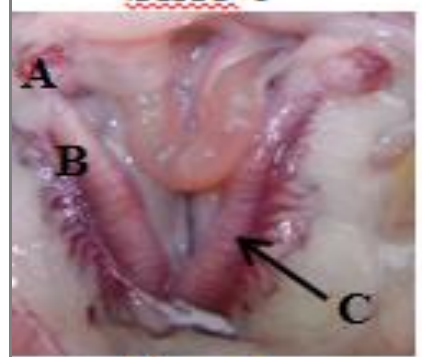

Skor 3

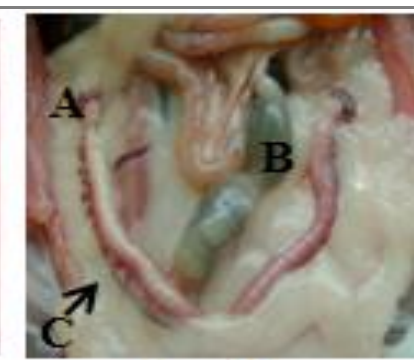

Skor 1

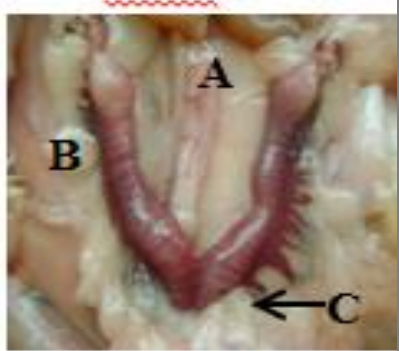

Skor 4

Gambar 2. Penampangan Ovarium dan

Uterus Pada Fase Estrus Tikus

Keterangan:

A (Ovarium); B (Uterus) dan C (Vaskularisasi). Skor 0 (tidak berwarna), skor 1 (sedikit merah), skor 2 (merah), dan skor 3 (sangat merah)

Tabel 2. Pengamatan Vaskularisasi Pada Ovarium dan Uterus

\begin{tabular}{cccccc}
\hline \multirow{2}{*}{$\begin{array}{c}\text { Kode } \\
\text { Hewan }\end{array}$} & \multicolumn{5}{c}{ Skor Warna Ovarium dan Uterus Pada Perlakuan } \\
\cline { 2 - 6 } & $\mathbf{P}_{\mathbf{1}}$ & $\mathbf{P}_{\mathbf{2}}$ & $\mathbf{P}_{\mathbf{3}}$ & $\mathbf{P}_{\mathbf{4}}$ & $\mathbf{P}_{\mathbf{5}}$ \\
\hline 1 & 3 & 0 & 3 & 3 & 3 \\
2 & 2 & 1 & 3 & 3 & 3 \\
3 & 2 & 1 & 3 & 2 & 3 \\
4 & 3 & 0 & 2 & 3 & 3 \\
Total & 10 & 2 & 11 & 11 & 12 \\
Rat-rata & $2,5^{\mathrm{a}}$ & $0,5^{\mathrm{a}}$ & $2,7^{\mathrm{c}}$ & $2,7^{\mathrm{c}}$ & $3^{\text {bc }}$ \\
\hline
\end{tabular}

Hasil Uji Duncan menunjukkan bahwa, semua perlakuan pemberian ekstrak etanol herba kemangi berpengaruh sangat nyata dibandingkan dengan etinil estradiol $9 \times 10^{-3} \mathrm{mg} / 200 \mathrm{gBB}$ pada vaskularisasi ovarium dan uterus pada tikus putih betina. Hasil penelitian ini dapat menjelaskan bahwa dengan dosis ekstrak kemangi terendah yaitu $0,8 \mathrm{~g} / 200 \mathrm{~g} \mathrm{BB}$ pengaruhnya sudah setara dengan dosis $1,6 \mathrm{~g} / 200 \mathrm{~g}$ BB dan dosis $3,2 \mathrm{~g} / 200 \mathrm{~g}$ BB dengan perbedaan yang sangat beda nyata terhadap vaskularisasi ovarium dan uterus tikus putih betina.

\section{Peningkatan Bobot Ovarium dan Uterus Pada Fase Estrus}

Pada permukaan ovarium terlihat adanya tonjolan-tonjolan yang diyakini dapat memperlihatkan perkembangan folikel. Hal ini menguatkan dugaan bahwa pada fase estrus telah terjadi perkembangan folikel secara maksimal yang siap diovulasikan (Dellmann, 1992). Data pengukuran bobot ovarium dan uterus yang dapat dilihat pada Tabel 3.

Hasil ini menunjukkan bahwa perlakuan ekstrak etanol herba kemangi pada konsentrasi terendah pun sudah setara 
dengan kontrol positif. Hasil pengujian berdasarkan rata-rata bobot ovarium dan uterus menunjukkan bahwa perlakuan ekstrak etanol herba kemangi pada dosis $3,2 \mathrm{~g} / 200 \mathrm{gBB}$ menunjukkan peningkatan bobot ovarium dan uterus yang paling tinggi bila dibandingkan dengan keempat perlakuan lainnya. Sedangkan pada kontrol negatif menunjukkan bahwa bobot ovarium dan uterus paling rendah dibandingkan dengan keempat perlakuan lainnya. Pada hasil pengujian skoring, menunjukkan bahwa perlakuan ekstrak etanol herba kemangi memberikan pengaruh yang sama $(\mathrm{P}>0,05)$ terhadap peningkatan bobot ovarium dan uterus tikus. Setelah di uji lanjut dengan Duncan, memperlihatkan hasil bahwa perlakuan pemberian ekstrak etanol herba kemangi dosis $0,8 \mathrm{~g} / 200 \mathrm{gBB}$, dosis $1,6 \mathrm{~g} / 200 \mathrm{gBB}$ setara pengaruhnya dengan kontrol positif (etinil estradiol) terhadap bobot ovarium dan uterus. Bahkan dengan pemberian dosis $3,2 \mathrm{~g} / 200 \mathrm{gBB}$ memperlihatkan bobot ovarium dan uterus yang lebih berat dibanding dengan kontrol positif secara beda nyata terhadap bobot ovarium dan uterus tikus.

Tabel 3. Data Penimbangan Bobot Ovarium dan Uterus Tikus Pada Setiap Perlakuan

\begin{tabular}{cllccc}
\hline \multirow{2}{*}{$\begin{array}{c}\text { Kode } \\
\text { Hewan }\end{array}$} & \multicolumn{5}{c}{ Pengukuran Bobot } \\
\cline { 2 - 6 } & $\mathbf{P}_{\mathbf{1}}$ & $\mathbf{P}_{\mathbf{2}}$ & $\mathbf{P}_{\mathbf{3}}$ & $\mathbf{P}_{\mathbf{4}}$ & $\mathbf{P}_{\mathbf{5}}$ \\
\hline 1 & 1,10 & 0,90 & 1,50 & 1,50 & 2,00 \\
2 & 1,50 & 1,50 & 2,00 & 1,50 & 2,00 \\
3 & 2,00 & 1,50 & 1,30 & 2,00 & 1,60 \\
4 & 2,00 & 1,00 & 2,00 & 2,00 & 2,00 \\
Total & 6,60 & 4,90 & 6,80 & 7,00 & 7,60 \\
Rat-rata & $1,65^{\mathrm{a}}$ & $1,23^{\mathrm{a}}$ & $1,70^{\mathrm{ab}}$ & $1,75^{\mathrm{ab}}$ & $1,90^{\mathrm{bc}}$ \\
\hline
\end{tabular}

Keterangan: Angka yang diikuti superkrip yang sama pada baris yang sama menunjukkan pengaruh yang tidak berbeda nyata $(\mathrm{P}>0,05)$ antar perlakuan

\section{SIMPULAN DAN SARAN Simpulan}

Perlakuan ekstrak etanol $70 \%$ herba kemangi (Ocimum americanum L.) dapat meningkatkan aktivitas estrogenik tikus putih betina (Rattus norvegicus) premenopause. Pada dosis $0,8 \mathrm{~g} / 200 \mathrm{~g}$ BB dapat memperpanjang siklus estrus, juga meningkatkan vaskularisasi dan meningkatkan bobot ovarium dibandingkan kontrol negatif (CMC-Na1\%). Perlakuan dengan konsentrasi terendah sudah setara dengan kontrol positif etinil estradiol $\left(9 \times 10^{-}\right.$ ${ }^{3} \mathrm{mg} / 200 \mathrm{~g}$ BB ).

\section{Saran}

a. Perlu dilakukan penelitian dengan menggunakan dosis yang lebih rendah pada penelitian ini.

b. Perlu dilakukan metode bioassay melalui pemeriksaan serum darah tikus untuk mendapatkan hasil yang lebih akurat.

\section{DAFTAR PUSTAKA}

Albrecth, E.D., and Pepe, G.J. 2007. Estrogen maintains pregnancy, triggers fetal maturation. http://www.sciencedaily.com/news/health_m edicine/pregnancy_and_childbirth [20 Juni 2013].

Banerjee, S., Prashar, R., Kumar, A. and Rao, A. R. (1996). Modulatory influence of alcoholic extract of ocimum leaves on carcinogenmetabolizing enzyme activities and reduced glutathione levels in mouse. Nutr Cancer, 25, 205-17.

Beimborn, V., H.L. Tarpley, P.J. Bain and K.S. Latimer. 2003. The canine estrous cycle: staging using vaginal cytological examination.

Bhardwaj, S., Mathur, R. 1979. Antifertility screening of fruits of Ocimum gratissimum in female albino rats. Comp Physiol Ecol. 4: 277-279.

Dellmann, H.D. 1992. Buku Teks Histologi Veteriner. Terjemahan: R. Hartono. 
Edisi ke-3 UI-Press. Jakarta: 517520.

Ganiswara, S.G. 1995. Farmakologi dan Terapi. Alih bahasa: 1. Setiawan. Buku Kedokteran EGC. Jakarta: 444.

Godhwani, S., Godhwani, J. L. and Vyas, D. S. (1987). Ocimum sanctum: An experimental study evaluating its anti-inflammatory, analgesic and antipyretic activity in animals. $J$ Ethnopharmacol, 21, 153-63.

Gunawan, D. 2004. Ramuan Tradisional Untuk Keharmonisan Suami Istri. Penebar Swadaya, Jakarta.

Hadipoentyanti, E., Wahyuni, S. 2008. Keragaman selasih (ocimum spp.) berdasarkan karakter morfologi produksi dan mutu herba. Jurnal Littri. Desember; 14 (4): 141-8.

Hafez, E.S.E. 1980. Reproduction in Farm Animal. $4^{\text {th }}$ Edition. Philadelphia: 30 78.

Harborne. 1987. Metode Fitokimia Penuntun Cara Modern Menganalisis Tumbuhan. Terjemahan: Kosasih Padmawinata. ITB. Bandung: 85-93..

Johnson M, and Everitt B. 1984. Essential Reproduction. $2^{\text {nd }}$ edition. London dan Beccles: William Clowes Limited

Karthikeyan, K., Ravichandran, P. and Govindasamy, S. (1999). Chemopreventive effect of ocimum sanctum on DMBA-induced hamster buccal pouch carcinogenesis. Oral Oncol, 35, 112-9.

Khare, C.P. 2007. Indian Medicinal Plants An illustrated Dictionary, Springer, New Delhi, 444.

Khazaei, M., Montaseri, A., Khazaei, M.R., Khanahmadi, M. 2011. Study of Foeniculum vulgare effect on folliculogenesis in female mice. Int. J. Fertill Steril. 5 (3): 122-127.

Medica, V., Ruslan, W., Nawawi, A., 2004. Telaah Fitokimia Daun Kemangi (Ocimum americanum L.). Fakultas Farmasi Institut Teknologi Bandung. Skripsi.
Nodine, J.H. and Siegler, P.E. 1961. Pharmacologic Techniques in Drug Evaluation. Year Book Medical Publisher. Chicago: 568.

Nongae, 2008. Estrus Cycle. http://nongae.gsnu.ac.kr/ cspark/teachi ng/chap5.html. Tanggal akses 2 Juni 2013.

Ochiogu, I.S., Oguejiofor, C.F and Nwagbo, A.N. 2009. Males Non- Enhancement of Bruce And Whitten Effects In Female Albino Mice - Mus musculus. Animal Research International. 6 (3): 1077-1081.

Piironen, V., Toivo, J. Puupponen-Pimi, R. and Lampi, A.M. 2003. Plant sterols in vegetables, fruits and berries. Journal of the Science of Food and Agriculture, 83: 330-337.

Rastogi, S., Shukla, Y., Paul, B.N., Chowdhuri, D. K., Khanna, S. K. and Das, M. 2007. Protective effect of Ocimum sanctum on 3-methylcholanthrene, $\quad 7,12-$ dimethylbenz(a)anthracene and aflatoxin b1. Nig. J, Physiol. Sci 224, 228-40.

Rugh, R. 1968. The Mouse Reproductions and Development. Burgess. Publishing Company. Minneapolis. USA.

Sarma, D.S.K. and A. Venkata S. B. 2011. Pharmacognostic And Phytochemical Studies of Ocimum americanum. J. Chem. Pharm. Res., 3 (3): 337-347.

Seire, J.V., Venter, F.S., Fincham, J.E., and Taljaard, J.J.F. 1991. Hormonal vagina cytology of vervet monkeys. J. Med Primatol. 20:1-5.

Setiawan. 2010. Aktivitas ekstrak methanol buah adas (Foeniculum vulgare Mill) terhadap lama siklus estrus serta bobot uterus dan ovarium tikus putih. Skripsi Fakultas Kedokteran Hewan. Institut Pertanian Bogor.

Smith, J.B. dan Mangkoewidjojo, S. 1988.Pemeliharaan, Pembiakan dan Penggunaan Hewan Coba Di Daerah Tropis. UI-Press. Jakarta: 10-3.

Sudjana, M.A. 1998. Metode Statistik. Edisi ke-5. Penerbit Tarsio. Bandung: 508. 
Suntoro, H. 1983. Metode Pewarnaan (Histologi \& Histokimia). Jakarta: Penerbit Bharatara Karya Aksara,

Turner, C.D. dan Bagnara, J.J. 1976.

Endokrinologi Umum. Harjoso, penerjemah. Surabaya: Airlangga University Press
Waynforth, H.B. and Flecknell P,A.1992. Experimental and Surgical Technique in the Rat. San Diego: Academic Press Inc.

Willmann, M.R. 2000. Sterols as regulators of plant embryogenesis. Trends in Plant Science, Journal Club, 5 (10): 416. 